\title{
Expression and molecular consequences of inhibition of estrogen receptors in granulosa cells of bovine follicles
}

\author{
Monique Tomazele Rovani ${ }^{1,4}$, Bernardo Garziera Gasperin², Gustavo Freitas Ilha ${ }^{1,4}$, Rogério Ferreira ${ }^{3}$, \\ Rodrigo Camponogara Bohrer ${ }^{4}$, Raj Duggavathi ${ }^{4}$, Vilceu Bordignon ${ }^{4}$ and Paulo Bayard Dias Gonçalves ${ }^{1 *}$
}

\begin{abstract}
Background: Estradiol (E2) receptors mediate E2 effects on cell proliferation and apoptosis under normal and pathological conditions. However, the mechanisms involved in E2 signaling are not completely understood. The objectives in this study were to evaluate the expression of estrogen receptors (ESRs) during follicular selection in cattle, and the effect of intrafollicular injection of fulvestrant (an antagonist of ESRs) on follicular development and transcript abundance in granulosa cells.

Methods: Granulosa cells were obtained from the two largest follicles around follicular deviation, after FSH treatment and after intrafollicular injection of fulvestrant. Ovarian follicular dynamics monitored by ultrasonography and quantitative real time PCR were used to validate the in vivo model and investigate the effects of FSH supplementation or ESR blockade on mRNA expression of estradiol-related genes.

Results: ESR1 and ESR2 were expressed in granulosa cells of both dominant (F1) and subordinate (F2) follicles, but their transcripts levels were higher in F1 than F2 after follicular deviation. FSH treatment maintained mRNA levels of both ESR1 and ESR2 in F2 follicles at similar levels observed in F1 follicles. Intrafollicular injection of $100 \mu \mathrm{M}$ fulvestrant inhibited follicular growth and decreased CYP19A1 mRNA levels. Transcript levels for both ESR1 and ESR2 were not affected by fulvestrant injection. Analyses of FSH-regulated genes revealed that ESRs inhibition in the dominant follicle decreased the transcript levels of the GJA1 but not those of PRKAR2B, MRO or LRP11 genes.

Conclusions: Our findings indicate that: both ESR1 and ESR2 are regulated during follicular deviation and dominance in cattle and in response to FSH treatment, and ESRs are required for normal gene expression and development of the dominant follicle. Furthermore, we have validated an in vivo model to study estrogen signaling during follicular development that allows paracrine signaling between different follicular cells in a physiological endocrine environment.
\end{abstract}

Keywords: Estrogen receptors, Follicular deviation, Fulvestrant, Intrafollicular injection, Bovine

\section{Background}

Follicular deviation is characterized by the selection of one follicle while the other follicles become atretic. Dominant follicles (F1) have greater concentrations of estradiol (E2) in follicular fluid when compared to subordinate follicles (F2) $[1,2]$. It has been shown that E2 protects granulosa cells from apoptosis, promoting cell cycle progression in

\footnotetext{
*Correspondence: bayard@ufsm.br

'Laboratory of Biotechnology and Animal Reproduction - BioRep,

Federal University of Santa Maria, Santa Maria, RS, Brazil

Full list of author information is available at the end of the article
}

healthy follicles [3], whereas subordinate follicles lose their ability to produce E2 and undergo atresia [4]. Besides its pivotal role during normal follicle development, E2 signaling also regulates ovarian cancer cell proliferation and apoptosis [5], being ESRs important prognostic biomarkers for ovarian cancer [6].

It is well established that E2 signaling is mediated by the intracellular receptors estrogen receptor 1 (ESR1) and estrogen receptor 2 (ESR2), which are members of the nuclear receptor superfamily [7]. In mouse ovaries, ESR1 is mainly expressed in interstitial cells, whereas ESR2 is 
localized in granulosa cells of growing follicles [8]. In mice, females lacking Esr1 gene are infertile and non-receptive to males, which indicates defective estrogen response in the central nervous system [9]. In order to circumvent the lack of ESR1-mediated action in the hypothalamic-pituitary axis, Couse et al. [10] administrated exogenous gonadotropins to Esr1 knockout mice and confirmed that ESR1 is required for ovulation. On the other hand, Esr2 knockout mice have lower number of growing follicles and reduced litter size compared to wild-type females [11].

Differentiation of granulosa cells in response to FSH is enhanced by estrogen $[12,13]$. Using in vitro knockout approaches, it was observed that ESR2 mediates estrogen actions. Indeed, ESRs were shown to be essential for differentiation of mouse granulosa cells in response to $\mathrm{FSH}$, and a critical factor for expression of $\mathrm{LH}$ receptor (LHCGR) but not for FSH receptor (FSHR) [14,15]. It was also demonstrated that ESR2 deletion impairs the cAMP pathway response to $\mathrm{FSH}$, changing the pattern of global gene expression and attenuating the expression of various FSH-regulated genes [15]. In cattle, it was shown that ESR2 mRNA expression is up regulated in fully differentiated follicles compared to subordinate follicles between days 2 and 3.5 of the estrous cycle [16]. However, the expression pattern of ESRs before, during and after follicle deviation has not been demonstrated. Moreover, the consequences of pharmacologic inhibition of ESRs during bovine follicular growth have not been investigated.

Intrafollicular injection in live animals represents an invaluable tool to investigate the physiological roles of ESRs during folliculogenesis. Indeed, the possibility of performing follicular manipulations in vivo while maintaining the complex follicular ultrastructure and cellular interactions circumvents the limitations of the in vitro models. Fulvestrant (ICI 182,780) is an antiestrogen that competes with E2 for binding to ESRs with no agonist activity [17]. Fulvestrant binds to ESRs and prevents their dimerization. The formed fulvestrant-ESR complexes are not translocated into the nucleus thereby culminating in the degradation of the complex [18].

In this study, we have used cattle as an in vivo model to: a) investigate the expression pattern of ESRs in the two largest follicles collected before, at the expected time-point, and after follicular deviation; b) evaluate the effect of FSH on ESRs expression; and c) determine the effects of ESRs inhibition on follicular development, and expression of ESRs and FSH-regulated genes in granulosa cells of developing follicles.

\section{Methods}

\section{Animals}

All procedures were approved by the Institutional Committee for Ethics in Animal Experiments at the Federal
University of Santa Maria, RS, Brazil. Adult cyclic Bos taurus taurus beef cows were used in this study.

\section{Estrus synchronization and follicular growth monitoring}

Cows used in experiments 1 and 2 (detailed below) were synchronized with two doses of a prostaglandin F2 $\alpha$ (PGF2 $\alpha$ ) analogue (cloprostenol, $250 \mu \mathrm{g}$; Schering-Plough Animal Health, Brazil) given intramuscularly (i.m.) 11 days apart. Animals observed in estrus within 3-5 days after the second PGF2 $\alpha$ administration were included in the experiments.

Cows used in experiment 3 were treated with a progesterone releasing intravaginal device (1 g progesterone, DIB - Intervet Schering Plough, Brazil), an im injection of $2 \mathrm{mg}$ estradiol benzoate (Genix, Anápolis, Brazil) to induce follicular regression and emergence of a new follicular wave, and two (12 h apart) im injections of PGF2 $\alpha$. Four days later, the progesterone device was removed and ovaries were monitored daily for at least 3 days before treatment to ensure that new follicles were growing and persistent follicles were not present in the ovaries. Only cows without a corpus luteum in an ultrasound exam were included in the study to avoid progesterone inhibitory effects during the final stage of follicular growth and ovulation.

In all experiments, ovaries were examined once a day by transrectal ultrasonography, using an $8 \mathrm{MHz}$ linear-array transducer (Aquila Vet scanner, Pie Medical, Netherlands) and all follicles larger than $5 \mathrm{~mm}$ were drawn using 3 to 5 virtual slices of the ovary allowing a three-dimensional localization of follicles and monitoring individual follicles during follicular wave [19].

\section{Ovary collection and isolation of granulosa cells}

Cows were ovariectomized by colpotomy under caudal epidural anesthesia [20]. Ovaries were washed with saline and granulosa cells were harvested from follicles through repeated flushing with PBS. Cell samples were immediately stored in liquid nitrogen for further analyses.

\section{RNA extraction, reverse transcription and real-time PCR}

Total RNA was purified from granulosa cells using silicabased protocol (Qiagen, Mississauga, ON, Canada) according to the manufacturer's instructions. Quantitation and estimation of RNA purity was performed using a NanoDrop spectrophotometer (Thermo Scientific - Waltham, USA; Abs 260/280 nm ratio). Ratios above 1.8 were considered pure, and samples below this threshold were discarded. Complementary DNA was synthesized from 500 ng RNA, which was first treated with $0.1 \mathrm{U}$ DNase, Amplification Grade (Life Technologies, Burlington, ON) for $5 \mathrm{~min}$ at $37^{\circ} \mathrm{C}$. After DNase inactivation at $65^{\circ} \mathrm{C}$ for $10 \mathrm{~min}$, samples were incubated in a final volume of $20 \mu \mathrm{l}$ with iScript cDNA Synthesis Kit (BioRad, Hercules, CA). 
Complementary DNA synthesis was performed in three steps: $25^{\circ} \mathrm{C}-5 \mathrm{~min}, 42^{\circ} \mathrm{C}-30 \mathrm{~min}$ and $85^{\circ} \mathrm{C}-5 \mathrm{~min}$.

To test cross-contamination with theca cells, quantitative PCR detection of Cytochrome P450, family 17, subfamily A, polypeptide 1 mRNA (CYP17A1; NM_174304.2; F: CCATCAGAGAAGTGCTCCGAAT; R: GCCAATGC TGGAGTCAATGA) was performed in granulosa cells. Samples were considered free of contamination if CYP17A1 was not amplified within 30 PCR cycles. Quantitative polymerase chain reactions ( $\mathrm{qPCR}$ ) were conducted in a CFX384 thermocycler (BioRad) using iQ SYBR Green Supermix (BioRad) and bovine-specific primers (Table 1) taken from the literature or designed using the Primer Express Software (Applied Biosystems). Standard two-step qPCR was performed with initial denaturation at $95^{\circ} \mathrm{C}$ for 5 min followed by 40 cycles of denaturation at $95^{\circ} \mathrm{C}$ for $15 \mathrm{sec}$ and annealing/extension at $58^{\circ} \mathrm{C}$ for $30 \mathrm{sec}$. Melting-curve analyses were performed to verify product identity.

To optimize the qPCR assay, serial dilutions of cDNA templates were used to generate a standard curve. The standard curve was constructed by plotting the log of the starting quantity of the dilution factor against the $\mathrm{Ct}$ value obtained during amplification of each dilution. Reactions with a coefficient of determination (R2) higher than 0.98 and efficiency between 95 to $105 \%$ were considered optimized. The relative standard curve method was used to assess the amount of a particular transcript in

Table 1 List of primers used in the qPCR reactions

\begin{tabular}{|c|c|c|}
\hline Gene name & Primer sequence $\left(5^{\prime}\right.$ to $\left.3^{\prime}\right)$ & $\begin{array}{l}\text { Reference or } \\
\text { accession no. }\end{array}$ \\
\hline \multirow[t]{2}{*}{ CYP19A1 } & F: GTGTCCGAAGTTGTGCCTATT & [21] \\
\hline & R: GGAACCTGCAGTGGGAAATGA & \\
\hline \multirow[t]{2}{*}{ ESR1 } & F: CCAACCAGTGCACGATTGAT & NM_001001443.1 \\
\hline & R: TTCCGTATTCCGCCTTTCAT & \\
\hline \multirow[t]{2}{*}{ ESR2 } & F: CAGCCGTCAGTTCTGTATGCA & NM_174051.3 \\
\hline & R: TCCTITTCAATGTCTCCCTGTTC & \\
\hline \multirow[t]{2}{*}{ FSHR } & F: AGCCCCTTGTCACAACTCTATGTC & [21] \\
\hline & R: GTTCCTCACCGTGAGGTAGATGT & \\
\hline \multirow[t]{2}{*}{ GJA1 } & F: GTCTTCGAGGTGGCCTTCTTG & NM_174068.2 \\
\hline & R: AGTCCACCTGATGTGGGCAG & \\
\hline \multirow[t]{2}{*}{ LHCGR } & F: GCACAGCAAGGAGACCAAATAA & NM_174381.1 \\
\hline & R: TTGGGTAAGCAGAAACCATAGTCA & \\
\hline \multirow[t]{2}{*}{ LRP11 } & F: CCAGAAAGTCGCATTGATCTTG & NM_001206831.1 \\
\hline & R: TGTTCCCCTCCTCCTCGATT & \\
\hline \multirow[t]{2}{*}{$M R O$} & F: CCCACTTACAGGACAGGAATCC & NM_001034552.1 \\
\hline & R: TGGAAGCTGTAGTCCTTGCTTTG & \\
\hline \multirow[t]{2}{*}{ PRKAR2B } & F: GGGCATTCAACGCTCCAGTA & NM_174649.2 \\
\hline & R: CTGGATTCAGCATCATCTTCTTCTT & \\
\hline
\end{tabular}

$F$, Forward primers; $R$, Reverse primers. each sample [22]. Samples were run in duplicate and results are expressed relative to GAPDH (NM_001034034.2; F: ACCCAGAAGACTGTGGATGG; R: CAACAGA CACGTTGGGAGTG), cyclophilin B (NM_174152.2; F: GGTCATCGGTCTCTTTGGAA; R: TCCTTGATCAC ACGATGGAA), RPL19 (NM_001040516.1; F: GCCAA CTCCCGTCAGCAGA; R: TGGCTGTACCCTTCCGC TT) and/or RPLPO (NM_001012682.1; F: GGCGACC TGGAAGTCCAACT; R: CCATCAGCACCACAGCCT $\mathrm{TC})$ or the average $\mathrm{Ct}$ values for these genes as internal controls. The selection of the internal control genes was based on the Ct variance (as reflected by the standard deviation) among groups in each experiment.

Experiment 1: Estrogen receptors expression in granulosa cells around the period of follicle deviation

Thirty-two cows were synchronized, of which the fifteen cows that were detected in estrus 3 to 5 days after the second PGF $2 \alpha$ administration were ovariectomized at specific stages of the first follicular wave. The day of follicular emergence was designated as day- 0 of the wave and was retrospectively identified as the last day on which the dominant follicle was 4 to $5 \mathrm{~mm}$ in diameter [23]. Separate groups of cows were randomly assigned for ovariectomy on days-2 $(n=4), 3(n=4)$ or $4(n=7)$ of the follicular wave to recover the two largest follicles from each cow. This approach allowed us to investigate transcript abundance of ESRs and related genes when the size of the largest and second largest follicle did not have a significant difference (day-2 of the follicular wave), had slight difference (day-3) or marked difference (day-4). These time-points correspond to before, during and after the dominant follicle selection, respectively.

\section{Experiment 2: Estrogen receptor expression after FSH treatment}

This experiment was conducted to compare mRNA levels of ESR genes between the two largest follicles collected from FSH $(\mathrm{n}=3)$ and saline $(\mathrm{n}=4)$ treated cows. FSH treated cows received two doses of $30 \mathrm{mg}$ FSH (Folltropin-V, Bioniche Animal Health, Ontario, Canada) on the second day of the estrous cycle followed by two doses of $20 \mathrm{mg}$ on the third day. Control cows were injected at the same time with saline. Ovaries were collected 12 hours after the last FSH/saline treatment and granulosa cells were recovered as described above.

Experiment 3: Effect of intrafollicular administration of an estrogen receptor inhibitor on follicular development and gene expression in granulosa cells

To determine the effective dose of the estrogen receptor inhibitor, fulvestrant (Sigma-Aldrich, Brazil), nine adult cyclic cows were synchronized as detailed above and their ovaries were monitored by transrectal ultrasonography. 
When the largest follicle of the growing cohort reached a diameter between 7 to $8 \mathrm{~mm}$, which represents the size when the future dominant follicle is reliably identifiable $[24,25]$, it was injected with 1,10 or $100 \mu \mathrm{M}$ (n =3/group) fulvestrant. Intrafollicular injection and adjustment of fulvestrant amount to be injected according to follicular size were performed as previously described [26]. The development of the injected follicles was monitored by daily ultrasound examination for three days after treatment.

Based on the inhibition of follicular growth (see the Results), the highest concentration of fulvestrant $(100 \mu \mathrm{M})$ was chosen to evaluate the effect of ESRs inhibition on gene expression in granulosa cells. Six cows were synchronized and their future dominant follicle was injected intrafollicularly with fulvestrant or saline ( $n=3$ per group). Cows were ovariectomized at $12 \mathrm{~h}$ after intrafollicular injection to harvest granulosa cells.

\section{Statistical analyses}

Variation in transcript levels was analysed by ANOVA and multiple comparisons between days or groups were performed by LSMeans Student's $t$ test using the JMP Software. Continuous data were tested for normal distribution using Shapiro-Wilk test and normalized when necessary. The effect of fulvestrant on follicular development was performed as repeated measures data using the MIXED procedure with a repeated measure statement using the SAS Software package (SAS Institute, Inc., Cary, NC, USA). Main effects of treatment group, day, and their interaction were determined. Differences between follicular sizes at a specific time point were compared between groups using estimates. Differences between the two largest follicles were accessed by paired Student's $t$-test using cow as subject. Results are presented as means \pm S.E.M. $\mathrm{P} \leq 0.05$ was considered statistically significant.

\section{Results}

Expression of ESRs during follicular selection and dominance

The respective diameters of the largest (F1) and the second largest (F2) follicles collected before (day-2), during (day-3) and after (day-4) deviation were $7.3 \pm 0.2 \mathrm{~mm}$ and $6.4 \pm 0.1 \mathrm{~mm}(\mathrm{P}>0.05), 8.1 \pm 0.2 \mathrm{~mm}$ and $6.5 \pm$ $0.4 \mathrm{~mm}(\mathrm{P}>0.05)$, and $9.5 \pm 0.2$ and $6.8 \pm 0.1(\mathrm{P}<0.0001)$. Using the same experimental model, we have previously shown that estradiol concentrations increased in the follicular fluid of F1 (dominant) follicles from day 2 to 4 , but decreased in F2 (subordinate) follicles on days 3 and 4 [24].

In order to validate the in vivo experimental models, we first assessed mRNA levels of Cytochrome P450, family 19, subfamily A, polypeptide 1 (CYP19A1) and $\mathrm{LH}$ receptor $(L H C G R)$ genes in granulosa cells from the largest and second largest follicles on days- $2(n=4), 3$ $(n=4)$ or $4(n=7)$ of the follicular wave. Subordinate follicles expressed low levels of CYP19A1 and LHCGR (Figure 1) during (day-3) and after (day-4) the expected time of follicular deviation. The relative mRNA abundance of ESR1 and ESR2 in granulosa cells was then compared between the largest (F1) and second largest (F2) follicles (Figure 1). While mRNA levels of ESRs were similar between F1 and F2 follicles before (day-2) and at (day-3) the expected time of follicular deviation, both ESR1 and ESR2 transcripts were higher $(\mathrm{P}<0.05)$ in $\mathrm{F} 1$ than $\mathrm{F} 2$ follicles after deviation (day-4).

\section{Effect of FSH treatment on ESR expression}

Based on the findings of the first study we evaluated whether FSH treatment would maintain normal expression of ESRs in the second largest follicles. Similarly to the first experiment, we confirmed that mRNA levels of

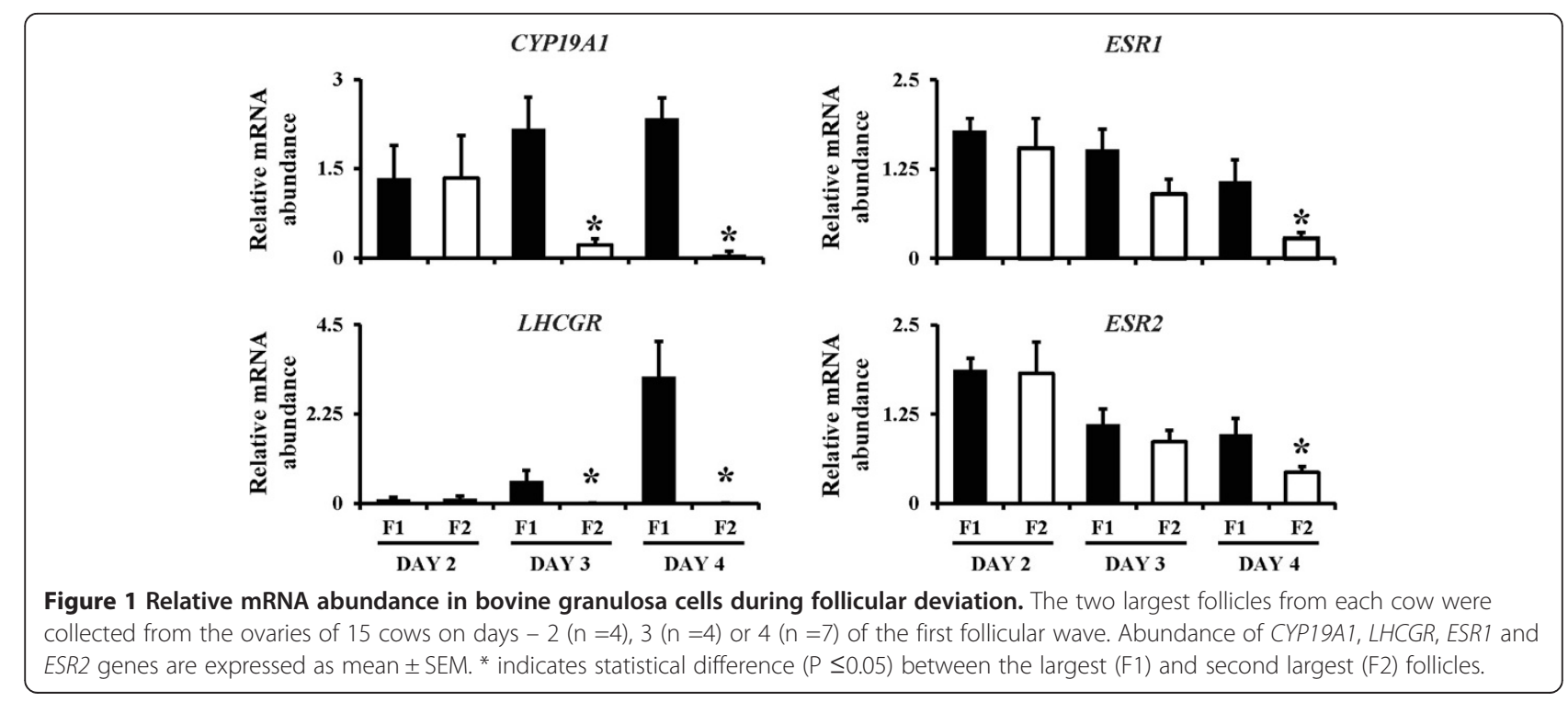


ESRs were higher $(\mathrm{P}<0.05)$ in $\mathrm{F} 1$ than $\mathrm{F} 2$ follicles after deviation (Figure 2). Yet, there was no difference $(\mathrm{P}>0.05)$ in either ESR1 or ESR2 mRNA levels between F1 and F2 follicles collected from FSH-treated animals (Figure 2). CYP19A1 mRNA abundance did not differ $(\mathrm{p}>0.05)$ between F1 $(0.6 \pm 0.13)$ and F2 $(0.33 \pm 0.11)$ follicles of FSH-treated cows, but was significantly higher $(\mathrm{p}<0.05)$ in F1 $(1 \pm 0.18)$ compared to F2 $(0 \pm 0)$ follicles from control cows.

\section{Effect of intrafollicular inhibition of ESRs on follicular development and ESRs expression}

Our next objective was to evaluate the consequences of inhibiting ESRs in growing follicles around the time of follicular deviation. We first monitored follicular growth in response to intrafollicular injection of 1,10 or $100 \mu \mathrm{M}$ fulvestrant in follicles having an average diameter of $8.8 \pm$ $0.6,7.8 \pm 0.1$ and $8.1 \pm 0 \mathrm{~mm}$ ( $\mathrm{P}>0.05)$, respectively. While follicular development was inhibited by the higher concentrations (10 and $100 \mu \mathrm{M}$ ) of fulvestrant (Figure 3; $\mathrm{P} \leq 0.01$ ), follicles injected with $1 \mu \mathrm{M}$ continued developing. This confirmed that the inhibition of follicular growth was specifically due to the higher concentration of

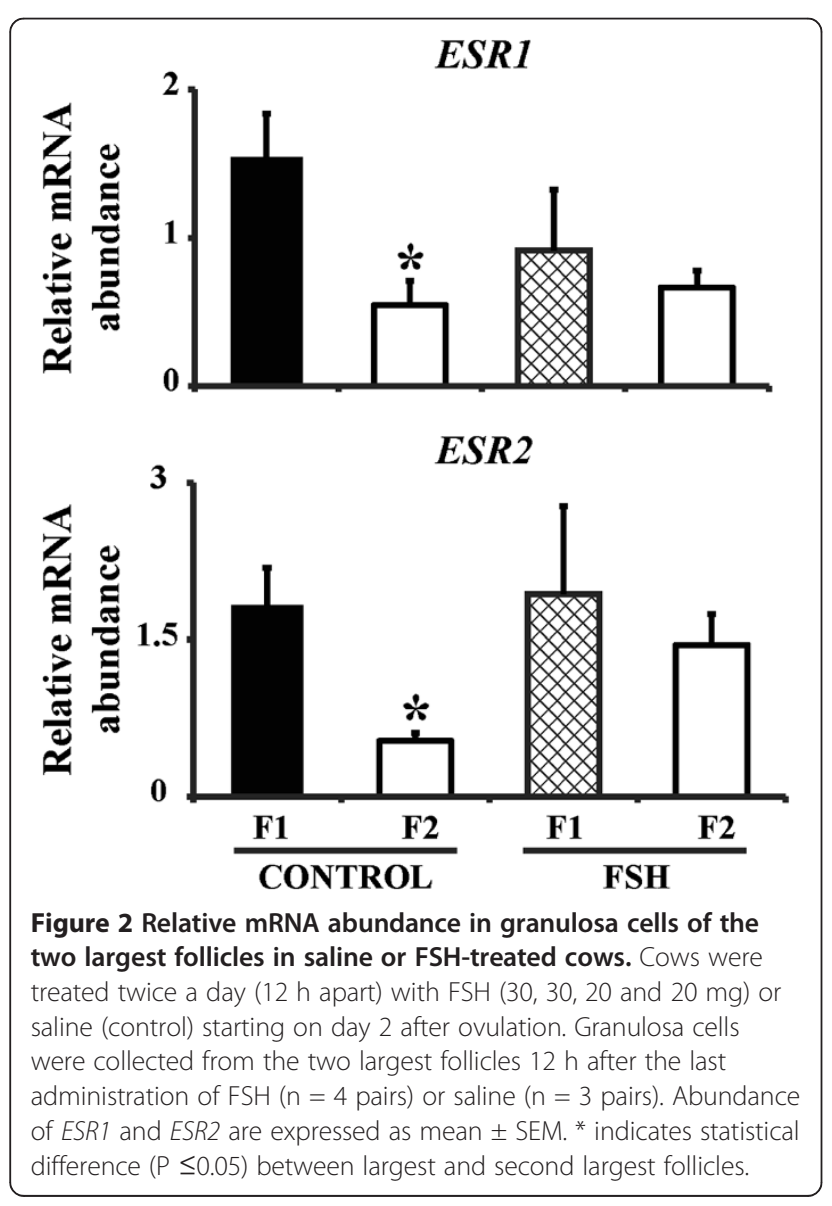

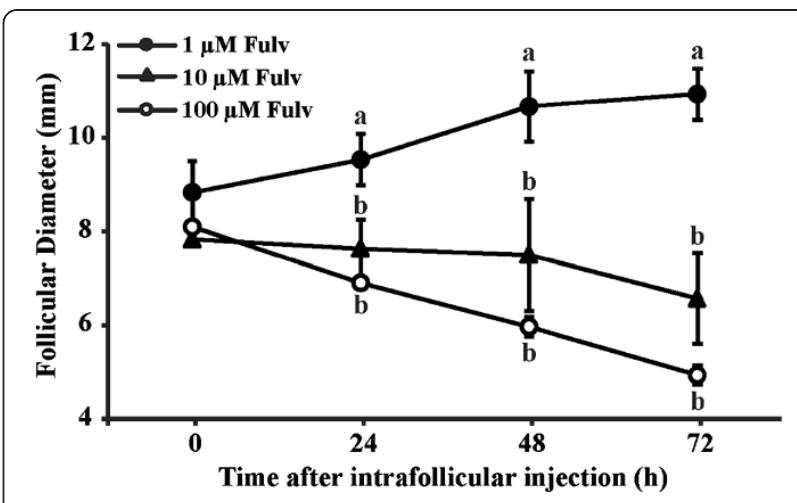

Figure 3 Effect of intrafollicular injection of an estrogen-receptor antagonist (fulvestrant) on follicular growth. A new follicular wave was induced (detailed in Methods) and 1, 10 or $100 \mu \mathrm{M}$ fulvestrant ( $n=3$ /group) was intrafollicularly injected when the largest follicle reached a diameter between 7 to $8 \mathrm{~mm}$. Follicular diameters were monitored by daily ultrasound examinations until $72 \mathrm{~h}$ after intrafollicular treatment. Different letters indicate significant differences $(P \leq 0.05)$ between treatments within a time.

fulvestrant rather than as a consequence of the intrafollicular injection procedure.

As expected, intrafollicular inhibition of ESRs with $100 \mu \mathrm{M}$ fulvestrant resulted in decreased abundance $(\mathrm{P} \leq 0.05)$ of mRNA encoding CYP19A1 (Figure 4). However, mRNA levels of LHCGR, ESR1 and ESR2 were not different between control and fulvestrantinjected follicles (Figure 4).

\section{Effect of ESRs inhibition on the expression of FSH- regulated genes in granulosa cells}

Our final objective was to evaluate the effect of intrafollicular administration of $100 \mu \mathrm{M}$ fulvestrant on granulosa cell gene expression. The diameters of F1 and F2 follicles used in this experiment were $9.5 \pm 1.3 \mathrm{~mm}$ and $6.1 \pm 0.6 \mathrm{~mm}(\mathrm{P}<0.05)$ in the control group, and $8.6 \pm$ $0.9 \mathrm{~mm}$ and $7.5 \pm 0.7 \mathrm{~mm}(\mathrm{P}>0.05)$ in the FSH-treated group. We focused on FSH-regulated genes such as Gap junction protein alpha 1 (GJA1), Maestro (MRO), Low density lipoprotein receptor-related protein 11 (LRP11), FSHR and Protein kinase, cAMP-dependent, regulatory, type II, beta (PRKAR2B), as these were reported to be downregulated in granulosa cells of Esr2 null mice [15]. We first examined if these genes are indeed differentially regulated in dominant and subordinate follicles using granulosa cells of F1 and F2 collected on day 4 of the follicular wave (Experiment 1). Relative mRNA levels of GJA1, MRO, LRP11, FSHR, but not PRKAR2B, were higher $(\mathrm{P} \leq 0.05)$ in granulosa cells of $\mathrm{F} 1$ than $\mathrm{F} 2$ follicles (Figure 5A). However, in granulosa cells of fulvestranttreated follicles only GJA1 mRNA was lower $(\mathrm{P} \leq 0.05)$ compared to granulosa cells of control follicles (Figure 5B). Fulvestrant treatment did not affect $(\mathrm{P}>0.05)$ the abundance of mRNA encoding PRKAR2B, MRO, LRP11 and 
CYP19A1
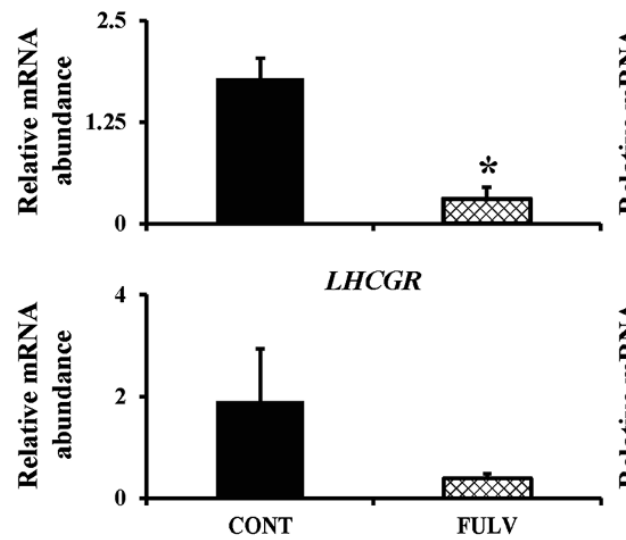

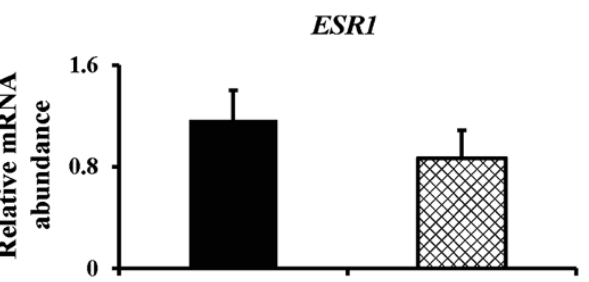

ESR2

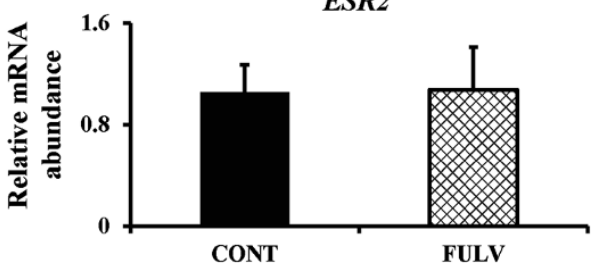

Figure 4 Relative mRNA abundance in granulosa cells of the largest follicle after intrafollicular injection of fulvestrant. A new follicular wave was induced (detailed in Methods) and $100 \mu \mathrm{M}$ fulvestrant or saline was intrafollicularly injected when the largest follicle reached a diameter between 7 to $8 \mathrm{~mm}$. Granulosa cells were recovered from saline $(n=3)$ and fulvestrant $(n=3)$ treated follicles at $12 \mathrm{~h}$ after intrafollicular injection. Abundance of CYP19A1, LHCGR, ESR1 and ESR2 genes are expressed as mean \pm SEM. * indicates statistical difference $(P \leq 0.05)$ between groups.

FSHR relative to granulosa cells of control follicles (Figure 5B).

\section{Discussion}

In this study, cattle were used as an in vivo model to investigate regulation of ESR 1 and 2 during follicular deviation in a monovular species, and the effects of intrafollicular inhibition of ESRs on follicular growth and gene expression. We observed that: expression of ESR1 and 2 was higher in granulosa cells of the largest compared to second largest follicle after deviation; FSH maintained expression of both ESRs in the second largest follicles beyond the follicular deviation; inhibition of ESRs abrogated follicular growth without decreasing their transcript levels and; FSHregulated genes respond differently to intrafollicular inhibition of ESRs in growing follicles.

Studies with mice have established that ESR2 is the receptor responsible for mediating estrogen actions in granulosa cells $[8,14,15]$. However, ESR1 has been proposed to be the main receptor involved in follicular development in cattle [27]. This suggests that regulation of ESRs may differ between monovulatory and polyovulatory species. In this study, we have confirmed that both ESR1 and ESR2 are expressed in granulosa cells during follicular selection in cattle. While the expression of ESR1 and ESR2 was significantly decreased in granulosa cells of the subordinate follicle after deviation, both ESRs were constitutively expressed in the selected dominant follicle. It is therefore possible that both receptors are required for the continued development of the dominant follicle during and after follicular deviation in cattle. Our primary objective in this study was to characterize the expression of ESRs before, during and after follicle deviation. Although expected to be regulated before follicle deviation, we observed that both ESR1 and ESR2 were regulated after deviation. This suggests that ESRs are not involved in follicular selection, but they are necessary to maintain follicular development of the selected follicles.

Although previous studies in rats have shown that hypophysectomised females express ESRs in granulosa cells in response to FSH [28], the effect of FSH treatment on the expression of ESRs during follicular growth has not been thoroughly investigated in cattle. Herein, we found that FSH maintained the expression of both ESR1 and ESR2 in the second largest follicle at similar levels observed in the largest follicle, while mRNA levels for both ESRs were reduced in the second largest follicle of saline treated cows. This suggests that similar to rodents, FSH promotes the expression of both ESRs in granulosa cells during follicular growth and selection in cattle.

To further investigate the roles of ESRs during follicular growth, we performed in vivo intrafollicular administration of the ESRs antagonist fulvestrant in cows. Fulvestrant is known to disrupt the dimerization and accelerate the degradation of ESRs $[29,30]$. We first confirmed that fulvestrant injection suppresses follicular growth in a dose depend manner, which, in addition to validate our in vivo model, indicated that ESRs are required for continued development of the dominant follicle after deviation in cattle. Intrafollicular injection in cattle is a well-established technique. We and others have previously shown that this procedure did not affect follicle growth and ovulation [25,26,31,32]. Indeed, the fact that follicles injected with the lower concentration of fulvestrant $(1 \mu \mathrm{M})$ continued to grow indicates that 

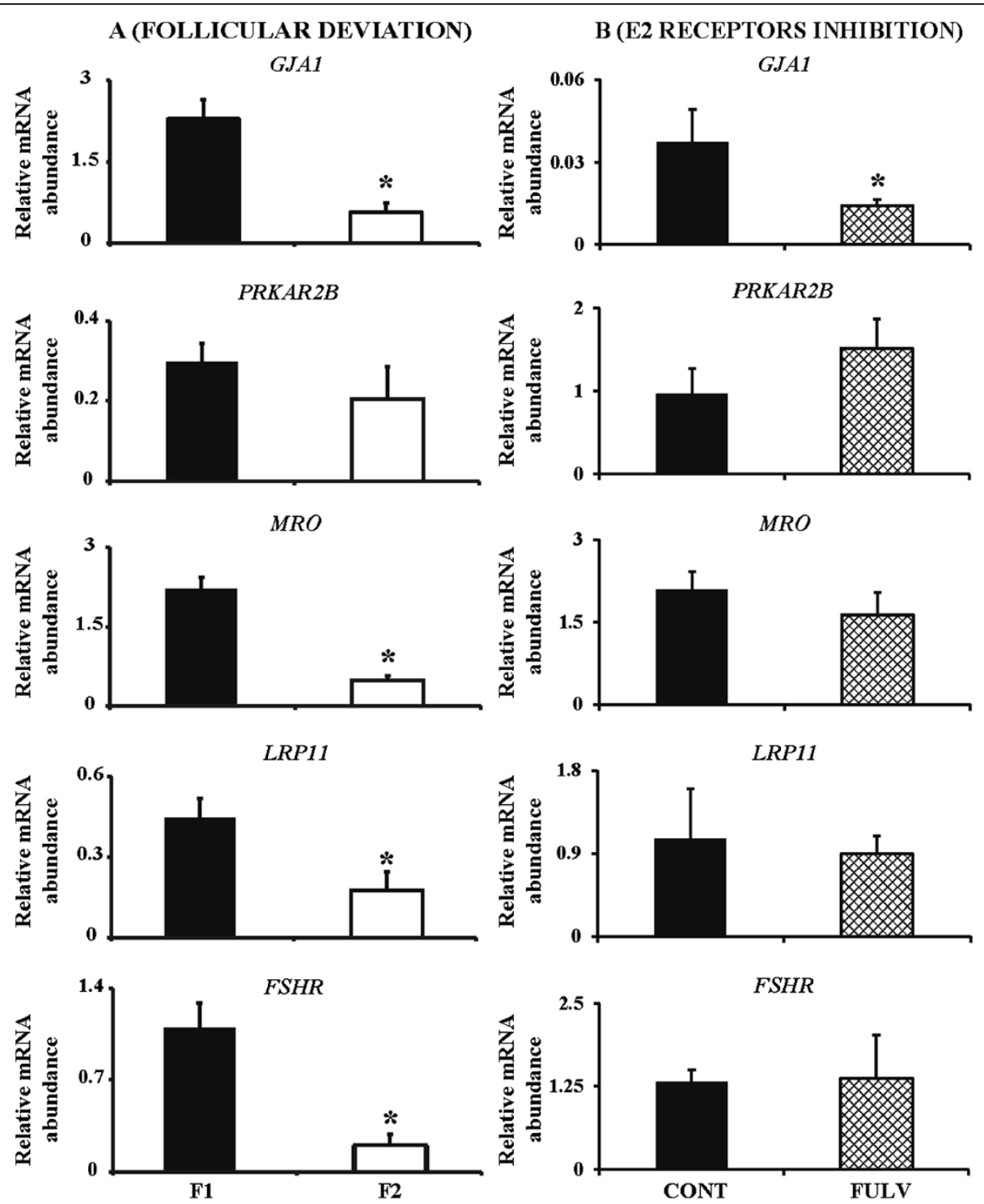

Figure 5 Relative mRNA abundance in granulosa cells after follicular deviation (A) and after fulvestrant treatment (B). Abundance of GJA1, PRKAR2B, MRO, LRP11 and FSHR genes are expressed as mean \pm SEM. In $\mathbf{A}$, asterisk $\left(^{*}\right)$ indicates statistical difference $(P \leq 0.05)$ between largest (F1) and second largest (F2) follicles after follicular deviation. In $\mathbf{B}$, asterisk $\left(^{*}\right)$ indicates statistical difference (P $\left.\leq 0.05\right)$ between groups: intrafollicular injection of saline or fulvestrant.

the intrafollicular injection procedure did not interfere with follicular development. Moreover, our data clearly show that only the higher concentrations of fulvestrant (10 or $100 \mu \mathrm{M}$ ) were able to block follicular growth and reduce CYP19A1 mRNA levels in granulosa cells. Estradiol concentrations were not determined in this study because we have previously reported that estradiol tended to be lower in the follicular fluid of fulvestrant-treated follicles compared to control follicles [33]. The inhibition of estrogen binding to its receptors by fulvestrant injection decreased the expression of CYP19A1, the enzyme responsible for androgen aromatization to estrogen, suggesting that estrogen regulates its own synthesis $[34,35]$. This is supported by our results from the follicular deviation model, where CYP19A1 mRNA levels were lower in subordinate follicles collected on day- 3 and 4 , which are known to have low estrogen levels [24,33]. Moreover, estrogen treatment has been shown to increase ESRs expression in granulosa cells of hypophysectomised rats [28]. On the other hand, we observed that transcripts levels of ESR1 and ESR2 were not affected by fulvestrant treatment. The aforementioned results validate fulvestrant intrafollicular injection as a valuable model to study estradiol signaling in granulosa cells. However, a model to study the specific functions of ESR1 and ESR2 still needs to be validated. 
Using knockout mice, Deroo et al. [15] identified FSHregulated genes that require Esr 2 for normal expression. Indeed, granulosa cells lacking Esr2 had lower transcript levels of Comp, Mro and Lrp11 genes after gonadotropin stimulation, whereas Prkar2b expression was not affected. In the present study, we observed no differences in transcript abundance of PRKAR2B, MRO or LRP11 genes in response to inhibition of ESR signaling. This suggests that pharmacological inhibition of ESRs was not sufficient to downregulate $M R O$ and LRP11 in monovulatory compared to polyovulatory species. It is still possible that genetic deletion of ESRs may result in phenotype similar to rodents. On the other hand, we observed that follicles treated with fulvestrant had significantly decreased mRNA levels of GJA1 compared to control follicles. The GJA1 provides the communication among granulosa cells via gap junction channels, and it was shown to be highly expressed in granulosa cells of rat follicles [36]. It has been well established that GJA1 is the most important connexin that makes a significant contribution to intercellular coupling in mouse granulosa cells and Gja1 null mice exhibit aberrant follicular growth [37]. It has also been reported that GJA1 mRNA and protein decrease during follicular atresia induced by E2 withdrawal in rodents [38]. Our findings with intrafollicular injection of fulvestrant demonstrate that the ESR signalling is necessary for GJA1 expression in granulosa cells of growing follicles of monovulatory species. Further, these observations indicate that inhibition of ESRs abrogates follicular growth at least in part through deregulated intercellular communication among granulosa cells. Taken together, our results indicate that the in vivo model used in this study represents an important asset to investigate steroid hormones signaling mechanisms in the ovary, which is needed for advancing our understanding of both physiological and pathological conditions [6].

\section{Conclusions}

Using an in vivo model of a monovulatory species, we have shown that both ESR1 and ESR2 are regulated in granulosa cells during follicular deviation and dominance, and in response to FSH treatment. Moreover, by intrafollicular injection of an antagonist, we confirm that ESRs are required for the normal development of the dominant follicle in cattle. Finally, we propose that intrafollicular injection in cattle is a suitable in vivo model to study estrogen signaling during follicular deviation and dominance in monovulatory species.

\section{Competing interests}

The authors declare that they have no competing interests.

\section{Authors' contributions}

MTR conducted the experiments, lab analyses, statistics and drafted the manuscript. BGG, GFI, RCB and RF participated in the collection of samples and experiments with live animals. BGG and RF contributed in the statistical analysis and writing. RD, VB and PBG designed the study, coordinated the experiments and revised the manuscript. All authors read and approved the final manuscript.

\section{Acknowledgements}

The authors are grateful to Dr Vinícius de Oliveira, Dr José Manoel Ferreira and Dr Olmiro Andrade Neto for providing the animals and animal work facilities. The authors disclosed receipt of the following financial support for the research, authorship, and/or publication of this article: Supported by CNPq and CAPES from Brazil, and the Natural Sciences and Engineering Research Council (NSERC) of Canada. MTR was supported by a scholarship from the Brazilian Council of Scientific and Technological Development (CNPq) as a visiting research trainee at McGill University.

\section{Author details}

'Laboratory of Biotechnology and Animal Reproduction - BioRep, Federal University of Santa Maria, Santa Maria, RS, Brazil. ${ }^{2}$ Departament of Animal Pathology, Federal University of Pelotas, Capão do Leão, Brazil. ${ }^{3}$ Department of Animal Science, Santa Catarina State University, Chapecó, SC, Brazil. ${ }^{4}$ Department of Animal Science, McGill University, Sainte Anne de Bellevue, QC, Canada.

Received: 2 July 2014 Accepted: 6 October 2014

Published online: 23 October 2014

\section{References}

1. Fortune JE: Ovarian follicular growth and development in mammals. Biol Reprod 1994, 50:225-232.

2. Badinga $L$, Driancourt MA, Savio JD, Wolfenson D, Drost M, De La Sota RL, Thatcher WW: Endocrine and ovarian responses associated with the first-wave dominant follicle in cattle. Biol Reprod 1992, 47:871-883.

3. Quirk SM, Cowan RG, Harman RM: The susceptibility of granulosa cells to apoptosis is influenced by oestradiol and the cell cycle. J Endocrinol 2006, 189:441-453.

4. Austin EJ, Mihm M, Evans ACO, Knight PG, Ireland JLH, Ireland JJ, Roche JF: Alterations in intrafollicular regulatory factors and apoptosis during selection of follicles in the first follicular wave of the bovine estrous cycle. Biol Reprod 2001, 64:839-848.

5. Modugno F, Laskey R, Smith AL, Andersen CL, Haluska P, Oesterreich S: Hormone response in ovarian cancer: time to reconsider as a clinical target? Endocr Relat Cancer 2012, 19:R255-R279.

6. Sieh W, Köbel M, Longacre TA, Bowtell DD, deFazio A, Goodman MT, Høgdall E, Deen S, Wentzensen N, Moysich KB, Brenton JD, Clarke BA, Menon U, Gilks CB, Kim A, Madore J, Fereday S, George J, Galletta L, Lurie G, Wilkens LR, Carney ME, Thompson PJ, Matsuno RK, Kjær SK, Jensen A, Høgdall C, Kalli KR, Fridley BL, Keeney GL, et al: Hormone-receptor expression and ovarian cancer survival: an ovarian tumor tissue analysis consortium study. Lancet Oncol 2013, 14:853-862.

7. Giguere V, Tremblay A, Tremblay GB: Estrogen receptor beta: re-evaluation of estrogen and antiestrogen signaling. Steroids 1998, 63:335-339.

8. Jefferson WN, Couse JF, Banks EP, Korach KS, Newbold RR: Expression of estrogen receptor beta is developmentally regulated in reproductive tissues of male and female mice. Biol Reprod 2000 62:310-317

9. Lubahn DB, Moyer JS, Golding TS, Couse JF, Korach KS, Smithies O: Alteration of reproductive function but not prenatal sexual development after insertional disruption of the mouse estrogen receptor gene. Proc Natl Acad Sci 1993, 90:11162-11166.

10. Couse JF, Bunch DO, Lindzey J, Schomberg DW, Korach KS: Prevention of the polycystic ovarian phenotype and characterization of ovulatory capacity in the estrogen receptor-a knockout mouse. Endocrinology 1999, 140:5855-5865.

11. Krege JH, Hodgin JB, Couse JF, Enmark E, Warner M, Mahler JF, Sar M, Korach KS, Gustafsson JA, Smithies O: Generation and reproductive phenotypes of mice lacking estrogen receptor beta. Proc Natl Acad SCi 1998, 95:15677-15682.

12. Richards JS, Hedin L: Molecular aspects of hormone action in ovarian follicular development, ovulation, and luteinization. Annu Rev Physiol 1988, 50:441-463. 
13. Tonetta SA, Spicer $\sqcup$, Ireland JJ: Cl628 inhibits follicle-stimulating hormone (FSH)-induced increases in FSH receptors of the rat ovary: requirement of estradiol for FSH action. Endocrinology 1985, 116:715-722.

14. Couse JF, Yates MM, Deroo BJ, Korach KS: Estrogen receptor-beta is critical to granulosa cell differentiation and the ovulatory response to gonadotropins. Endocrinology 2005, 146:3247-3262.

15. Deroo BJ, Rodriguez KF, Couse JF, Hamilton KJ, Collins JB, Grissom SF, Korach KS: Estrogen receptor beta is required for optimal cAMP production in mouse granulosa cells. Mol Endocrinol 2009, 23:955-965.

16. Evans ACO, Ireland JLH, Winn ME, Lonergan P, Smith GW, Coussens PM, Ireland JJ: Identification of genes involved in apoptosis and dominant follicle development during follicular waves in cattle. Biol Reprod 2004, 70:1475-1484

17. Wakeling $A E$, Dukes $M$, Bowler J: A potent specific pure antiestrogen with clinical potential. Cancer Res 1991, 51:3867-3873.

18. Wittmann BM, Sherk A, McDonnell DP: Definition of functionally important mechanistic differences among selective estrogen receptor down-regulators. Cancer Res 2007, 67:9549-9560.

19. Jaiswal RS, Singh J, Adams GP: Developmental pattern of small antral follicles in the bovine ovary. Biol Reprod 2004, 71:1244-1251.

20. Drost M, Savio JD, Barros CM, Badinga L, Thatcher WW: Ovariectomy by colpotomy in cows. J Am Vet Med Assoc 1992, 200:337-339.

21. Luo W, Wiltbank MC: Distinct regulation by steroids of messenger RNAs for FSHR and CYP19A1 in Bovine Granulosa Cells. Biol Reprod 2006, 75:217-225.

22. Cikos S, Bukovska A, Koppel J: Relative quantification of mRNA: comparison of methods currently used for real-time PCR data analysis. BMC Mol Biol 2007, 8:113.

23. Evans AC, Fortune JE: Selection of the dominant follicle in cattle occurs in the absence of differences in the expression of messenger ribonucleic acid for gonadotropin receptors. Endocrinology 1997, 138:2963-2971.

24. Ferreira R, Gasperin B, Santos J, Rovani M, Santos RA, Gutierrez K, Oliveira JF, Reis AM, Goncalves PB: Angiotensin II profile and mRNA encoding RAS proteins during bovine follicular wave. J Renin Angiotensin Aldosterone Syst 2011, 12:475-482.

25. Ferreira R, Gasperin B, Rovani M, Santos J, Barreta M, Bohrer R, Price C, Goncalves PB: Angiotensin II signaling promotes follicle growth and dominance in cattle. Endocrinology 2011, 152:4957-4965.

26. Ferreira R, Oliveira JF, Fernandes R, Moraes JF, Gonçalves PB: The role of angiotensin II in the early stages of bovine ovulation. Reproduction 2007, 134:713-719.

27. Berisha B, Pfaffl MW, Schams D: Expression of estrogen and progesterone receptors in the bovine ovary during estrous cycle and pregnancy. Endocrine 2002, 17:207-214.

28. Richards JS: Estradiol receptor content in rat granulosa cells during follicular development: modification by estradiol and gonadotropins. Endocrinology 1975, 97:1174-1184.

29. Robertson JF: ICI 182,780 (Fulvestrant)-the first oestrogen receptor down-regulator-current clinical data. Br J Cancer 2001, 85(Suppl 2):11-14.

30. Osborne CK, Wakeling A, Nicholson RI: Fulvestrant: an oestrogen receptor antagonist with a novel mechanism of action. Br J Cancer 2004, 90:S2-S6.

31. Barreta MH, Oliveira JFC, Ferreira R, Antoniazzi $A Q$, Gasperin $B G$, Sandri LR, Goncalves PBD: Evidence that the effect of angiotensin II on bovine oocyte nuclear maturation is mediated by prostaglandins E2 and F2 \{alpha\}. Reproduction 2008, 136:733-740.

32. Gasperin BG, Ferreira R, Rovani MT, Santos JT, Buratini J, Price CA, Goncalves PB: FGF10 inhibits dominant follicle growth and estradiol secretion in vivo in cattle. Reproduction 2012, 143:815-823.

33. Gasperin BG, Ferreira R, Rovani MT, Bordignon V, Duggavathi R, Buratini J, Oliveira JFC, Gonçalves PBD: Expression of receptors for BMP15 is differentially regulated in dominant and subordinate follicles during follicle deviation in cattle. Anim Reprod Sci 2014, 144:72-78.

34. Yue W, Berstein LM, Wang J-P, Clark GM, Hamilton CJ, Demers LM, Santen $\mathrm{RJ}$ : The potential role of estrogen in aromatase regulation in the breast. J Steroid Biochem Mol Biol 2001, 79:157-164.

35. Adashi EY, Hsueh AJ: Estrogens augment the stimulation of ovarian aromatase activity by follicle-stimulating hormone in cultured rat granulosa cells. J Biol Chem 1982, 257:6077-6083.
36. Wiesen JF, Midgley AR Jr: Changes in expression of connexin 43 gap junction messenger ribonucleic acid and protein during ovarian follicular growth. Endocrinology 1993, 133:741-746.

37. Juneja SC, Barr KJ, Enders GC, Kidder GM: Defects in the germ line and gonads of mice lacking connexin43. Biol Reprod 1999, 60:1263-1270.

38. Wiesen JF, Midgley AR Jr: Expression of connexin 43 gap junction messenger ribonucleic acid and protein during follicular atresia. Biol Reprod 1994, 50:336-348.

doi:10.1186/s13048-014-0096-0

Cite this article as: Rovani et al:: Expression and molecular consequences of inhibition of estrogen receptors in granulosa cells of bovine follicles. Journal of Ovarian Research 2014 7:96.

\section{Submit your next manuscript to BioMed Central and take full advantage of:}

- Convenient online submission

- Thorough peer review

- No space constraints or color figure charges

- Immediate publication on acceptance

- Inclusion in PubMed, CAS, Scopus and Google Scholar

- Research which is freely available for redistribution 